\title{
Research on Teaching of Piano Art History Courses in Chinese and Russian Colleges and Universities
}

\author{
Zuping Xu \\ Heihe University \\ Heilongjiang, China 164300
}

\begin{abstract}
As the extending course of musical history, piano art history course is focusing on the developing history of western piano art, of which it has made a detailed arrangement in a macro way. It has also strengthened the understanding of composing style by different composers in different time and regions. In this way, we can know the creating purpose of the composers exactly, which can also help us raise playing skills, express the artistic connotation of the composers' works and perform them much better. What's more, piano art history course is a required theoretical course, which is of great importance for the learning of piano majors.
\end{abstract}

Keywords - Chinese and Russian colleges and universities; piano art history courses; teaching

\section{INTRODUCTION}

The content of teaching about the developing of piano works is the key point of piano art history course, which is a branch course of history of western music. The time division of piano art history is basically according to that of western music history which is well-acknowledged. Its teaching process mainly focuses on the piano works and their composers. The following are their basic time frame structure: Time before Baroque, the Early and Mid-Baroque, the Late Baroque, Classicism Period, Classical-Romantic Period, Romantic Period, Nationalism in music in the 19th century, Impressionism Period and Time after the 20th Century. The method of "point-line-area" should be used by the teachers during the process of teaching piano art history. That is to say, they should collect all the point of piano works in its development, make clues and then connect all of them to form the whole context of the development of western piano art works by analyzing important works. In this way, students can have a clear and comprehensive knowledge about it. While, in this case, it is vital to recognize the "points", then understand and collect them at last. And those are exactly what will be talked about in this paper, which is the materialization and depth of piano art course teaching.

\section{Focus On the MEANING OF TEACHING Piano ART HISTORY}

Learning piano art history is an important way for students to get the knowledge of the overall development of piano art systematically. It can not only help them touch the history of

Fund project: Youth Academic Backbones of Heihe University.

Fund project: This paper is a staged achievement of 2015 planning project of art and science in Heilongiang province-Research on Teaching of Piano Art History Courses in Chinese and Russian Colleges and Universities. Project number: 2015B006 piano art development and improve music appreciation ability, but also help them learn to play the piano in a systematic and theoretical way. The meaning of teaching piano art history is presented in the following three aspects:

\section{A. Learn More about Western Music History and the Development of Culture to Improve Cultivation of Piano Art}

As a main part of the world's music, piano music plays an important in the developing of modern music, especially the western music history. Because of its special artistic fascination, piano music has made it possible for musician from different period and especially those great musicians to create quantity of works which are the treasure of human art. Piano was once loved by Chopin, Mozart, and Beethoven in their lifetimes, they devoted themselves to piano art. In this way, we can get a picture of western art history indirectly from whole art history. Piano music does not appear and exist on its own, but with the developing of culture and historical circumstances. With the development of economy, culture, industry and manufacture, piano art also changes a lot. What's more, it grows a lot along with the increased ability of art aesthetic and artistic quality.

\section{B. Clarify the Development of Piano Art Systematically to Broaden Students' Vision}

At present, what the piano majors learn is just the skills of how to play piano well in a systematical and professional way. In this case, they are lacking the knowledge of piano theory, what they concern is just the note, rhythm, melody and the skills of how to play the piano well. However, they just learn little about the composers, background of works, playing style and theory during their playing. Things can be changed by learning piano art history, because it can help make the development of piano art in a clear manner and promote the learning of piano in a comprehensive and systematical way. Knowledge of piano is infinite, even the great artists cannot grasp all of it, let alone students. Because of the limitation on time, place and skills, the piano majors can't piano knowledge comprehensively. But by learning the piano art history, they are able to get the knowledge of works from different time, nations and composers and then know the esthetic characteristic of works in different styles. From this point, the teaching of piano art history can help broaden the vision of students and different works in different styles and the 
development of piano playing skills, which can't be known by solely teaching skills.

\section{FocUS ON THE WAY OF TEACHING PIANO ART HISTORY}

The current music teaching system is mainly focus on the practice instead of exploring the theory. It is a difficulty for students and even the teachers to study courses like piano art history which concern wide range of knowledge and works from different time by different people. The traditional teaching methods are focusing on the teaching by teachers. While the students just listen to their teachers' talking and take notes, but there is little that they can remember. In this case, the teaching is not so effective. The method "Teaching Is Learning" should be adopted to enhance the communication between teachers and students. This can help make the students more positive and become the main part of teaching practice. Besides, as the information is developing rapidly, the teaching of piano knowledge should also be information-based. Using modern multimedia to present the monotonous piano art history, which can make it more diversified. This kind of revolution can help the unification of teaching mode and content. At the same time, opera can also be applied to enhance the diversification of piano art history. During the creation of operas they can not only learn how to communicate and be considerate and generous, but also can know the truth of responsibility, listening and tacit understanding. Opera can also build the students' ability of role consciousness and team spirit. All those features are of great importance in the teaching of piano art history.

\section{FOCUS ON THE DIVERSIFICATION OF TEACHING METHOD}

"Piano Art History" is a theoretical course mainly teaching in the classroom. And there will be much for students to appreciate, which is not contained in the practical teaching content. By this way, we carry out "Performance Research" teaching method by electing a certain work by a composer or by comparing works in different style from a certain period and region. So the students can understand the works better by playing it themselves, they can also know the features of works in different styles. What's more, this teaching method makes them more independent in artistic thinking and imagination. The work of composer need performer to play it. The excellent melody promote the improvement of performing skills, meanwhile, the intention of the composer need a skillful performer to express. In this case, content of the development of piano playing skill is necessary in the course "Piano Art History". Practice is better than just learn it from the book. Because when students know the basic concept and are able to analysis some composing works, they can become more interested in art by comparing different works, discussing the logic of music and exploring the essence of those works under the leadership of teachers. And it can be an effective and interesting teaching method.

\section{FOCUS ON THE COMBINATION OF DEVELOPMENT AND COMPARISON}

In general, the teaching of piano art history is in line with time order, which can help the students know the main structure of its development. But there are usually some branches and things intertwining with each other. So main point pattern should be drown and arranged in a crisscross, clear and multi-layered manner. It can help students know art history in a deep and comprehensive way. The teaching should be carried out mainly in a vertical manner, because in this way there can be much comparison in vertical type. For example, the comparison of music style, genre, melody, harmonic texture and playing style in different time. Meanwhile, different projects can be made to do more research. What's more, transverse arrangement should be made, such as the comparison of music style by different musicians in same period (sonatas by Mozart and Haydn) and works by the same musicians in different time and field (Sonatas by Beethoven in different time). Whatever the comparison is, it can be multiaspect and multi-view. In this way, students can get a clear picture about the development law and features of piano art and know better about those works.

\section{FOCUS ON THE COMBINATION OF PIANO ART HISTORY IN CHINA AND WESTERN COUNTRIES}

Piano art is origin from Europe, so it should be the main point for piano learners. While, it has been hundreds of years that the piano art from western countries in China. And it is well-developed and becomes a main part of the world's piano art. So what we need to learn is not only the development of that in western countries, but also in China. There has already been some representative works with distinctive Chinese style which have combined both Chinese and western culture. This success owes to the efforts by generations of musicians in China. Piano works like Chinese Cowboy with His Flute which is the first piano music with distinctive Chinese style and Yellow River Piano Concerto, the one that represents Chinese national spirit. With a history of more than a hundred years, Chinese piano art has enjoyed its sound development with both excellent works and musicians. There are many Chinese pianists have reputation in the world, such as Liu Shikun and Yin Chengzongin the mid-20th century and young pianist like Lang Lang and Li Yundi in recent years. Chinese piano works are formed by the combination of western piano music and Chinese folk music, so they have Chinese characteristics. In this way, it allows the performers to be familiar with Chinese music instruments and professional in touching key, pedaling, tone and harmony. Because of the big difference in styles between Chinese and western piano music, it is vital for knowing the development of Chinese piano art, in this way, we can get a clear picture of Chinese piano art style.

\section{GRASP THE MUSIC STYLE OF DifFERENT PiANO WORKS}

Though it is an important part of music art, performing skill can't represent all. On the contrary, it is of great importance to express the meaning and style of those works. Recent years, there are many outstanding Chinese pianists in the world stage, which means that piano education in China is becoming better and better. However, there are also some 
problems for it in China. We are used to focus more on skills, instead of the expression of music, which is regretful. While, piano music is origin from European countries, it is unavoidable for Chinese students to have some misunderstanding of it because of the difference lies in culture, region and nation.

\section{CONCLUSION}

In a word, it is the teachers' goal to make the coursepiano art history a platform for students to learn about piano art and to help them make improvements. While it is an endless subject for us to combine theory and practice to carry out this course much better. We need to improve this course according to the condition of students, such as clarifying teaching method and content and exploring the way of teaching. It is also necessary to sum up experience, adjust teaching plan and diversify the way of teaching to fulfill this course. In this case, there will be sound development for piano art history course along with relevant research. And I believe our teaching aim that improving students' ability of performing and teaching will be reached in the end.

\section{REFERENCES}

[1] Zhou Wei. History of Western Piano Art. [M].Shanghai. Shanghai Music Publishing House, 2003.1.

[2] Zhang Qian. Course of Music Aesthetics.[M].Shanghai. Shanghai Music Publishing House,2002.165-169.

[3] Lin Hua. I Love Bach. [M].Shanghai. Shanghai Music Publishing House, 274-277.

[4] Qi Wanxue. Higher Education Pedagogics.[M].Jinan.Shandong People's Publishing House. 99-100.

[5] Yu Runyang. Selections of Music Aesthetics.[M].Beijing.Central Conservatory of Music Press 454-478.

[6] Zhou Wei. The Past and Present of Piano Teaching Research[J]. Piano Art.2005(01)

[7] Xu Xun. Analysis on the Study of Western Piano Art History in China According to Reveral Research Articles[J].Journal of Nanjing Art University,2004(04) 